\title{
Influence of behavior, personal ability and leadership on cooperative performance in Aceh Province, Indonesia
}

\author{
Syamsul Rizal
}

Lecture of Academy of Finance and Banking (AKUBANK) Nusantara. Aceh, Indonesia and College student of Post-Graduate Doctor of Management Sciences (DIM) of Syiah Kuala University, Banda Aceh, Indonesia

\begin{abstract}
This research was conducted to see the effect of behavior, personal ability and leadership on cooperative performance in Aceh Province. Data were obtained by distributing questionnaires to several respondents. Data processing follows multiple linear. The results showed that the behavior affects the performance of cooperatives, personal capabilities affect the performance of cooperatives, leadership affect the performance of cooperatives in Aceh Province. Behavior, personal ability and leadership simultaneously affect the performance of cooperatives in Aceh Province.
\end{abstract}

Keywords: behavior, personal ability and leadership, performance

\section{Introduction}

Human resources is one important asset that must be owned by a company or organization which must be fostered as possible, on the other hand also need a serious handling of the low quality of human resources (Jisung Park: 2015). The availability of reliable human resources make the company can utilize human resources effectively and efficiently, for it needed a quality (Amstrong and Taylor 2012 : 33), the provision of adequate facilities, and the availability of employment is a major challenge that should be considered by the government, especially the Government of Aceh.

Economic globalization and highly competitive business competition become a challenge for economic (Neihaus and Price 2012). Currently the cooperative in Aceh is not yet able to develop rapidly compared with other business actors, this is because the Cooperative is still faced with the problem of performance that is still not optimal. In order to survive in the business competition climate, cooperatives must continue to consolidate internally to grow cooperatives in order to run its role in the economy (Skarvopa 2015). Community trust must be improved by growing cooperatives as a healthy, viable and member-oriented business entity. Therefore, the cooperative should be able to improve its competitiveness such as improving the ability of management, capital, mastery of cutting-edge technology and high skills to handle various business activities of the cooperative is expected to improve its performance so as to become an independent, creative and innovative people's economic power to realize people's welfare ( Jac Fitz 2011 : 112).

According to Law No. 25 of 1992 on cooperatives it is explained that the cooperative is a business entity consisting of a person or legal entity based on the principle of cooperative and as a people's economic movement based on the principle of kinship. Given the importance of the role of saving and loan cooperatives in supporting the economic activities of the community, the Aceh Provincial Government seeks to coach saving and loan cooperatives, not only through financial assistance to strengthen the capital of cooperatives, but through related government agencies also seek to improve cooperative management capability through training (training) management of cooperative management it is aimed at cooperatives can grow and develop in society and have an active role in encouraging economic activity of lower class society (Donell and Elizabeth Macknight 2012).

The development of cooperatives in Aceh Province based on active and inactive status during 2012 until 2017 can be seen as in the table below:

Table 1:Development of Cooperatives Based on status (active and inactive) In Aceh Province during the period 2012 - 2017 


\begin{tabular}{|c|c|c|c|c|c|}
\hline \multirow{2}{*}{ Year } & \multirow{2}{*}{$\begin{array}{c}\text { Total } \\
\text { Cooperation }\end{array}$} & $\begin{array}{l}\text { Total } \\
\text { (units) }\end{array}$ & Percent (\%) & Total & Percent (\%) \\
\cline { 3 - 6 } & & 3.153 & 65.20 & 1.683 & 34.80 \\
\hline 2012 & 5.533 & 2.994 & 59.75 & 2.017 & 40.25 \\
\hline 2013 & 5.800 & 3.352 & 60.58 & 2.181 & 39.42 \\
\hline 2014 & 6.612 & 3.910 & 67.41 & 1.890 & 32.59 \\
\hline 2015 & 6,570 & 4.051 & 66.28 & 2.061 & 33.72 \\
\hline 2016 & 6.614 & 4.246 & 64.63 & 2.324 & 35.37 \\
\hline 2017 & 7.079 & & & \\
\hline
\end{tabular}

Source: Dinas Koperasi dan UKM Provinsi Aceh 2017

Until January of 2017 there were 7,079 existing cooperatives in Aceh Province as many as 2,324 inactive status, and only 4,246 cooperatives with active status or still doing operational activities. From 2,324 the number of inactive cooperatives are mostly engaged in savings and loan business (USP) whose existence is very important in encouraging economic activities of society (Daily Newspaper Serambi Indonesia)

Increasing the number of inactive cooperatives is certainly a separate issue for the government in developing small and medium enterprises (UMKM) in this area is caused by micro enterprises such as households run savings and loan cooperatives as an alternative financing option or obtain loans for business needs when they do not have access to bank financial institutions.Since that issue of cooperative savings and loan is considered necessary to get serious attention from local government for the cooperative can run as expected.

\section{Special purpose}

In accordance with the issues discussed above, this particular objective is as follows.

a. To know the behavior of cooperative leadership on cooperative performance in Aceh Province

b. To know the personal ability of cooperative leadership in improving cooperative performance in Aceh Province

c. To know the competence of cooperative leadership toward cooperative performance in Aceh Province

d. To know the performance of the leadership of cooperatives in motivating the work of cooperative employees in Aceh Province

\section{Significance of Urgency (Priority) Research}

This study is considered very urgent along with the development of cooperatives in Aceh. Given the many cooperatives in Indonesia Especially in Aceh failed because at the beginning of the lack of vision of the formation and lack of clarity of goals to be achieved. Based on data from the Office of Cooperatives and UKM of Aceh Province (2017) in January of 2017 there were 7,079 existing cooperatives in Aceh Province as many as 2,324 inactive status, and only 4,246 cooperatives with active status or still doing operational activities. Of 2,324 the number of inactive cooperatives are mostly engaged in savings and loan business (USP) whose existence is very important in encouraging economic activities of the community. Given the increasing number of inactive cooperatives is certainly a separate issue for the government in developing small and medium enterprises (UMKM) in this area is due to micro-enterprises such as home industries run savings and loan cooperatives as an alternative financing option or obtain loans for business needs when they are not have access to bank financial institution. Therefore, the problem of saving and loan cooperatives is deemed necessary to get serious attention from local government for the cooperative can run as expected. Hopefully, by knowing the value of linkage between Behavior, Personal Ability and Cooperative Leadership Competence will become reference to stake holder in cooperative management and make policy.

\section{Literature Review}

\section{Definition of Behavior}

Behavior is influenced by thoughts, feelings, physiological processes and behavioral consequences. Behavior modification is a form that seeks to see that the individual is not only understood through apparent behavior as seen by the behaviorist, but behind the behavior that appears to be an internal process which is actually the result 
of thought (Ivey 2012). The underlying assumptions of behavior modification are:

a. Not adaptive leads to the formation of behavior

b. Adaptive self-improvement can be pursued through positive thinking enhancement

c. Employees can learn increased thinking about attitudes, thoughts, and behavior.

\section{Definition of Personal Ability (Personal Skill)}

Personal skills are tantamount to personality skills, which will explain behavior and actions that reflect the personality of the nation to understand and recognize the value of religious, social, and state values and have broad views and sensitivity to various personality problems. (O.Pesamaa T.Pieper R.Vinhas, 2012) Every individual must have personality, and the personality of each individual is different from that of the other. The way a person behaves and thinks is reflected by the person's personality. Personality is a dynamic organization of the psycho-physical system that determines individual behavior and individual thinking. (Jandf, 2011) Occurrence Psycho-physical interaction directs human behavior. What is dynamic in that sense is that behavior may change through learning or through experiences.

Based on the research framework that has been described previously, the research ypothesis can be expressed as follows.

\section{Definition of Leadership}

Aspects of Leadership is the ability to create productive and effective teams, encouraging team members' spirit and commitment to work better for the achievement of organizational goals and always appreciate the work performed by the work team. (Jaqueline A.Gilbert, 2013) In relation to leadership, this emphasis also includes the leadership design to improve coordination and performance by providing team work guidance and coaching teamwork. The coaching of the team is manifested in the form of motivational efforts (encouraging employee motivation). The consultation includes the willingness of the leadership to provide inserts related to the smooth implementation of duties by employees. Further education is related to the ability of the leadership to improve the skills and work skills of the employee (Richart E.Boyatzits, 2012)

\section{Hypothesis}

H1: Leadership Behavior of Cooperatives Affects Cooperative Performance in Aceh.
H2: Personal Capabilities Leadership Cooperative affects the performance of Cooperatives in Aceh,

H3: Cooperative Leadership Competence affects the performance of Cooperatives in Aceh,

\section{Research Methods}

\section{Object of research}

The current study is about the Influence of Behavior and Personal Ability and Leadership on the Performance of Cooperatives in Aceh.dimana assessed in accordance with the current situation and condition of Aceh. This research will discuss on 4 (four) Aspects which include:

a. Leadership Behavior

b. Functional Roles (Functional Roles)

c. Personal Capabilities and d. Personal Skill (Personal Skill)

The individual criteria can be explained as follows

\section{Individual Skill}

\section{Leadership Behavior ( Leadership Behavior)}

Leadership behavior refers to what is owned by the leadership of the cooperative, specifically the competencies related to leadership behavior including divergent thinking, critical thinking, creative, able to solve problems arise and think strategically. In relation to Leadership Behavior as one of the key leadership competencies of saving and lending cooperative Leadership behavior is manifested in the form of behaviors played by the leadership of the cooperative. (Kanfer and Golstein, 2011)

\section{Functional Roles (Functional Roles)}

Functional role of a leader determines the competence of the leader, in relation to functional as one of the key factors of leadership competence of this cooperative analysis is related to the extent to which the leadership of the savings and loan cooperatives play the role and function in accordance with the demands of duties and responsibilities given to him. Laserve \& Gracagna Dante, 2011)

\section{Individual Capability (Personal Capability)}

Persona Capability (Personal Capability) is an unlimited ability only in skill, but more than that is more understood in detail so that really master the ability from the point of weakness to how to overcome them. The key factor of cooperative leadership is related to personal capability related to the leadership of the cooperative in carrying out 
tasks that are in accordance with the responsibility. Capabilities are

is intended not only to be related to the general capabilities ideally possessed by each leader, but also the technical capability in managing cooperatives especially in lending, to the evaluation of credit / loan or financing performance to the general public and members of cooperatives is one of pertsonal capability indicators (Lagunna Wie Chetek and Talik, 2012)

\section{Individual Skill}

Personal Skill (personal skills) related to the skill or technical capability that should be owned by the leader in accordance with the demands of the task given to him. A leader must be skilled in managing relationships with members of the cooperative, but also must have the ability to manage cooperative relationships with various stakeholders including with the local government and related agencies that can affect the development of cooperatives. (O.Pesamaa T, 2013) Leadership kopersai are required to have better emotional intelligence so as to be a problem solver ata various problems faced.selain it understands against the use of information technology, bookkeeping cooperatives and the ability received by either by everyone is also an indicator personal skill of a leader including the leadership of savings and loan cooperatives (Pieper R, Vinhas, 2013) Cooperative environment always changes according to the development in society therefore, in order to exist and can maintain its business. Savings and loan cooperatives are required to adapt to environmental changes This implies that a person in charge of savings and loan cooperatives in carrying out their duties and authority in managing the cooperative should be oriented to efforts to maintain the continuity of cooperative efforts in a dynamic environment. With the management of cooperative katalain must be able to adjust with the changes taking place, in this case the leadership competence in following the change becomes important as one of the benchmarks of the success of the leadership of the cooperative that it plays. (Jac Fitzs, 2011) Community development is a very important intellectual capital for the success of saving and loan cooperatives. Intellectual capital is concerned with community development efforts which in this case are members of cooperatives are believed to be an important condition for the success of saving and loan cooperatives. In this research, the indicators of community development as one of the aspects of leadership competence (Ulrich, 2011) is the ability of the cooperative leadership to provide guidance on the use of loan / financing funds in accordance with the purpose of lending, especially related to business development of cooperative members.

\section{Populasi dan Sampel}

\section{Populasi}

Population is a generalization region consisting of objects or subjects that have certain qualities and characteristics set by the researchers to be studied and then drawn conclusions. The population in this study is all existing cooperatives in Aceh Province. The population in this study amounted to 107 people (Cooperative) covering all existing cooperatives in Banda Aceh City, East Aceh District, Central Aceh Regency, and Southwest Aceh Regency in Aceh Province.

\section{Sample}

The sample is part of the number and characteristic possessed by a population to be studied. Determination of the sample in this study was conducted with the type of Non Probability Sampling, this type of sample is not selected randomly, Not all elements or elements of the population have the same opportunity to be selected to be sampled. Non-Probability Sampling technique chosen by Convenience Sampling is the respondent as a sample by chance, ie anyone who by chance met with the researcher can be used as a sample if the person who happens to be found suitable as a source of data, The advantage of this technique is located at the accuracy of the researcher select the data source according to the variables studied.

\section{Types and Data Sources}

The type of data used is a cross-sectional data, because researchers collect data only during field research. While the data source used is primary and secondary. Researchers obtained primary data by distributing questionnaires to company employees who have been determined as respondents. While the secondary data obtained by conducting literature study of references related to issues to be studied, company records, and journals that discuss about the variables in this study.

\section{Data collection technique}

The data collection here is intended to get a score that serves as a relationship Leadership of Savings and Loans Cooperative in Banda Aceh City, East Aceh District, Kabupaten Aceh Tengah, and Kabupaten Aceh Barat Daya in Aceh Province, then Primary data is obtained through interviews and questionnaires. Questionnaires prepared in the form of choice of answers in accordance with the 
perception of respondents, namely in the form of closed questions. Measurement data conducted in this study using Likert scale.

\section{Quantitative Analysis}

Quantitative analysis is done by using statistics for data that require measurement. Quantitative analysis aims to determine the effect of independent variables to dependent variable. To test the influence of 2 (two) or more independent variables to one dependent variable is expressed by the following formula.

Formula: $\mathrm{Y}=\alpha+\beta 1 \mathrm{X} 1+\beta 2 \mathrm{X} 2+\beta 3 \mathrm{X} 3+\mathrm{e}$

$\mathrm{Y}=$ dependent variable, ie employee performance

$\alpha=$ intercept

$\beta 1=$ regression coefficient of variabel 1

$\beta 2=$ regression coefficient of variable 2

$\beta 3=$ regression coefficient of variable 3

$\mathrm{X} 1=$ independent variable 1

$\mathrm{X} 2$ = independent variable 2

$\mathrm{X} 2=$ independent variable 3

$\mathrm{e}=$ residual error

\section{Hypothesis testing}

\section{F Test}

Used to test the significance level of research model by measuring the influence of Cooperative Leadership Competence variable to Employee Performance, with Testing Criteria:

a. Ho accepted and Ha rejected if $\mathrm{F}$ arithmetic $\leq \mathrm{F}$ table, so there is no influence significant from $\mathrm{X} 1$ to $\mathrm{X} 2$, and $\mathrm{X} 1$ and $\mathrm{X} 2$ to $\mathrm{Y}$.

b. Ho is rejected and Ha accepted if $\mathrm{F}$ arithmetic $>\mathrm{F}$ table, so there is significant influence of $\mathrm{X} 1$ to $\mathrm{X} 2$, and $\mathrm{X} 1$ and $\mathrm{X} 2$ to $\mathrm{Y}$.

\section{t Test}

This test aims to examine the effect of free variables (Cooperative Leadership Competence) to the dependent variable (employee performance) separately or partially. The hypothesis used in this test is as follows:

Ho: Independent variables (Cooperative Leadership Competence has no positive and significant influence on the variables of custody (employee performance).

$\mathrm{H}_{1}$ : The independent variables (Cooperative Leadership Competence) have a positive and significant influence on the dependent variable (employee performance). With decision making.

\section{Research sites}

The location of this study took the study area in 4 districts / cities namely, Banda Aceh City, East Aceh District, Central Aceh District, and Southwest Aceh District in Aceh Province. The data processing of the research and analysis will be carried out in the Doctoral Program of Post Graduate Program of Syiah Kuala University with the schedule.

\section{Results and Discussion}

\section{Correlation}

The correlation coefficient of product moment ( $r$ ) will show the degree of correlation or tingat closeness of relationship between independent variable that is behavior, personal ability and leadership with dependent variable that is cooperative performance in Aceh Province.

The result of calculation of correlation coefficient value which gives guidance about behavioral relationship, personal ability and leadership with cooperative performance that is equal to $r=0,685$. It is clear that the value of this coefficient is positive, so it provides a clue to the close relationship between behavior, personal ability and leadership to the performance of cooperatives in Aceh Province. The correlation between behavior, personal ability and leadership with employee performance is in the strong category.

Hypothesis for significance test of correlation is there is real relation between behavior, personal ability and leadership with performance of cooperative in Aceh Province. Testing Criteria: Accept Ho if thitung < ttabel or $t$ count $<\mathrm{t} 0,05$ (n-2) in other case is rejected. it turns thitung $=5,796$ which means $>$ t0,99 $(43)=2,416$. The result of the test is to reject Ho stating "there is no relationship between behavior, personal ability and leadership with employee performance" and accept $\mathrm{Ha}$ which states "There is a relationship between behavior, personal ability and leadership with cooperative performance. Thus, behavior, personal ability and leadership significantly influence the performance of cooperatives in Aceh Province.

\section{Regression Analysis}

Because it has been proven that there is relationship between behavior, personal ability and leadership with cooperative performance, then to calculate regression analysis obtained result of regression equation as follows:

$\mathrm{Y}=13.2+0.526 \mathrm{X} 1+0.672 \mathrm{X} 2+0.624 \mathrm{X} 3$

From the regression equation above can be informed that: (1) Intersept of 13.02 means if the 
behavior, personal ability and leadership examined constant or zero value, the cooperative performance increased by 13.02 ; (2) The value of the regression coefficient of 0,526 means that if the behavior increases by 1 scale in the respondent's answer then the performance of cooperatives in Aceh Province will increase by 0.526 . The value of personal ability regression coefficient of 0.672 means that if the personal ability increases by 1 scale in the respondent's answer then the performance of cooperatives in the province of Aceh will increase by 0.672 . The value of leadership regression coefficient of 0.624 means if the leadership increases by 1 scale in the respondent's answer then the performance of cooperatives in Aceh province will increase by 0.624 .

\section{Conclusion and recommendation}

\section{Conclusion}

Based on the results of research that has been stated in the previous chapter can be concluded that: (1) The above calculation results can be the value of correlation coefficient that provides clues about the relationship behavior, personal ability and leadership with the performance of cooperatives. The result of correlation coefficient value stated that the relationship between behavioral variable, personal ability and leadership with employee performance in categorize strong and high enough. It is clear that the value of this coefficient is positive, so it provides a clue to the close relationship between behavior, personal ability and leadership to the performance of cooperatives in Aceh Province; (2) From the regression equation above can be informed that the behavior, personal ability and leadership examined constant or zero value, the performance of cooperative in Aceh Province equal to 13,02 . The value of behavioral regression coefficient of 0.526 , personal ability of 0.672 leadership of 0.624 means that if the behavior, personal ability and leadership increased by 1 scale in the answers of respondents then the performance of cooperatives in Indonesia will increase. Assuming other factors are considered fixed. In other words, this calculation means that each addition of 1 unit to the behavior, personal ability and leadership, then the performance of the cooperative will also rise; (3) Calculation of hypothesis testing, in the above analysis of the results of previous statistical tests. Thus the hypothesis Ho rejected, and accept Hypothesis Ha. behavior, personal abilities and leadership have a strong relationship with the performance of cooperatives in Aceh Province.

\section{Recommendation}

Based on the conclusion that has been mentioned above, the writer can give some suggestions as follows: (1) Leadership of cooperative in Aceh Province able to inspiration in work and determine direction and purpose of organization. The leadership of the cooperative in Aceh Province should be able to demonstrate its capacity to delegate responsibilities carefully and instill a strong sense of organization to its employees. This behavior, personal ability and leadership that affects employees to be able to commit to their organizations; (2) Leadership of cooperatives should play an active role in improving cooperative performance seen from the elements of behavior, personal ability and leadership both in terms of timeliness of task completion, work efficiency, work discipline, work effectiveness, the level of completion of duties, attendance or attendance to be good example for employees; (3) Leadership of cooperatives in Aceh Province should be more motivated employees to be able to improve its performance because in order to improve the performance of employees need the development of employees through employee education and training.

\section{References}

[1] Amstrong and Taylor,2012, Human Resources Pratice, Cogan Page, London

[2] Augusty, Ferdinand, 2012.Structural Equation Modeling dalam PenelitianManajemen AplikasiRumit dalam Penelitian Untuk TesisMagister \& Disertasi Doktor Edisi 2. Universitas Diponegoro, Semarang.

[3] Boyazits Richard,2011, Journal Managerial and Leadership Competencies : A Behavioral Approach to Emotional Social and Coqnitive Intelegence, Sage, Washington DC

[4] Davist,Keith and John w.newton.2015. Human Behavior at work organization Behavior,seventh edition,Mc.Graw-hill book Company

[5] Dessler and Gary,2010, Human Resources Management,Eght Edition, Prentice Hall International Inc.

[6] George Laserve \& Cracagna Dante and Garzon,2013,Journal Leadeship,Capacity Building and Governability in Cooperatives, EDUCC, Colombia

[7] Gordon,and Wayne, Athur and Shane,2013, Management and Organization Behavior,Allyn and Bacon,College, Boston 
[8] Ivey,Simek L. Morgan, 2012, Journal Consoling and Physcoterahy Multicultural Perspective,Devision of Simon and Schuster inc, Boston

[9] Jandt,2011, Process Interpersonal Communication,Harper and Row Publisher inc, New York

[10] Jac Fitzs,enz,2011,Human Capital ROI in New Technology,Hamburk

[11] Jacqueline A Gilbert, John Ivancevich,2013, Journal Toxic Versus Cooperative Behavior at Work : The Role of Organizational Culture and Leadership in Creating Community Centered Organizations, University of Houston USA.

[12] John Burgoyne, Wandt Hirsh and Sadies Williams,2013, Journal The Development of Management and Leadership Capability and its Contribution to Peformance : the Evidence,the Prospect the Research need, Departement of Education and skill, Lancaster University

[13] Laguna,Wiechetek, Talik W,2012, Vol 1 no 3 Journal Business Review The Competencies of Managers and Their Business Succes, University of Lublin, Poland.

[14] Mc Donell and Elizabeth Mach Night, 2012,Journal The Cooperative Model in Pratice, University of Aberdeen, Scotlandia

[15] Neuhaus and Price,2011, Organization Behavior A Global Perspective, 2 nd Edition, John Willey \& son Australia,Ltd

[16] O,Pesamaa,T,Pieper R,Vinhass,2012, Journal Trust and Peciprocity in Building Interpersonal and Inter Organizational Commitment in Small Business Cooperatives, of Co- operatives Organization and Management,Elsevier

[17] Richard Niehaus and Price Karl,2013.Human Resources Competitive, Creating Competitive Edge Throught HR Aplication, Spinger, Berlin

[18]Robbins, Stephern 2011 Organization Behavior, Concepts, Controversies, Application.Seventh Edition, Englewood Cliffs dan PT. Prenhallindo, Jakarta

[19] Smuntny Pets,2010, Human Resources and Personal Management. United Statet of America

[20] Skarvopa Ludmila,Grosova Stanislava,2015, Journal Vol 7 ISSN 1804-17X The Application of Business Network Approach for Small and Medium Enterprises (SME) with regard to their Buying
Behavior,University of chemistry and Technology Praha Chec Republic

[21]Skalova.2011, Vol 22 no 1 ISSN 17269679 Journal Population Growth and Human Resources Management, Publishing by DAAAM International,Vienna Austria.

[22] Spencer \& Spencer,2013, Competencie and Peformance Organizational,Mc Grow Hill, International Newyork.

[23] Ulrich and Wayne Youger,Mike,2012,Human Resources from the oud side in,Brock Bank,Mc Grow Hill,Newyork. 